\title{
Adrenergic Nervous System in Sodium Metabolism: Effects of Guanethidine and Sodium-retaining Steroids in Normal Man*
}

\author{
John R. Gill, Jr., Dean T. Mason, and Frederic C. Bartter with the \\ tech nical assistance of Ernest Powell and Isabelle M. Ambrose
}

(From the Clinical Endocrinology Branch, National Heart Institute, Bethesda, Md.)

Increased activity of the sympathetic nervous system (SNS) has been thought to be partly responsible for sodium retention in congestive heart failure, since sympatholytic drugs may increase the renal excretion of sodium in dogs (1) and patients (2) with congestive heart failure. Two other observations support the suggestion that changes in adrenergic activity may produce changes in renal function. Infusions of norepinephrine, the neurohumoral transmitter of the SNS, can decrease the excretion of sodium in normal subjects and in patients with Addison's disease (3). Patients with autonomic insufficiency excrete sodium at supranormal rates during infusions of normal saline (4). In the present investigation, sodium excretion during infusion of saline and during the administration of a sodium-retaining steroid has been studied before and after sympathetic blockade by guanethidine. The results of these studies provide additional evidence for a role of the SNS in sodium metabolism.

\section{Methods}

The subjects were four normal female volunteers, 17 to 24 years, and two patients, R.L. and Z.M., 34 and 43 years, respectively, who complained of "swelling" but had no demonstrable abnormalities. They were maintained on an air-conditioned ward and given metabolic diets with the intake of sodium varied according to the needs of the study. Body weight, determined with metabolic scales daily on arising, was used to provide a gross estimate of changes in the volume of body fluids. Sodium excretion during rapid sodium loading and during prolonged administration of a sodium-retaining steroid was observed in the following two types of studies.

1) After 3 or more days on a sodium intake of $109 \mathrm{mEq}$ per day, $2 \mathrm{~L}$ of physiologic saline containing inulin and

* Submitted for publication July 25, 1963; accepted October 7, 1963.

Presented in part at the 2nd International Congress of Nephrology, Prague, Czechoslovakia, August 1963. para-aminohippurate was infused by a Bowman constant infusion pump at a rate of $17 \mathrm{ml}$ per minute. All infusions were done in the morning, with the subjects fasting and recumbent. Urine was collected from an indwelling bladder catheter, with air washes at the end of each of six 20-minute periods of infusion and each of the three 10-minute periods that preceded and followed the infusions. Venous blood for inulin and para-aminohippurate was obtained at the mid-point of each 20-minute period through an indwelling Cournand needle.

The responses to saline infusion were again determined in each subject in the same manner after adrenergic blockade had been produced by guanethidine, an agent that depletes the body of catecholamines (5) and impairs transmission of the nervous impulse by postganglionic sympathetic fibers (6). The dosage of guanethidine was adjusted so that both diastolic and systolic blood pressure fell moderately when the subjects changed from a supine to a standing position, and so that the circulatory reflexes which are initiated by release of the Valsalva maneuver were absent [Figure 4, desoxycorticosterone acetate (DOC) and guanethidine]. The dosage of guanethidine required ranged from 20 (D.B.) to 75 (S.W.) $\mathrm{mg}$ and was given for 5 (S.W.) to 35 (Z.M.) days before the infusion of saline.

2) After 7 or more days on a balance regimen consisting of a sodium intake of $250 \mathrm{mEq}$ per day, DOC, $20 \mathrm{mg}$ per day intramuscularly, or 2-methyl-9 $\alpha$-fluorohydrocortisone, $0.5 \mathrm{mg}$ per day orally, was given to the subjects until body weight ceased to rise and was steady or falling. The responses to steroid were again determined in all subjects, in the same manner, after they had been on a sodium intake of $250 \mathrm{mEq}$ per day and guanethidine intake of 20 (D.B.) to 200 (K.O.) $\mathrm{mg}$ per day for 4 (K. O.) to 18 (Z.M.) days.

The resting brachial arterial pressure (mean arterial pressure, MAP) and the circulatory response to the Valsalva maneuver were measured directly through a Cournand needle attached to a Statham P-23D manometer and recorded with a multichannel photographic recorder. With the arm flat on the table, venous pressure was measured from a large antecubital vein with a water manometer and a no. 18 needle.

Serum, urinary, fecal, and dietary sodium and potassium were determined by internal standard flame photometer, and creatinine in serum and in 24-hour pools 
TABLE: I

Effect of guanethidine on sodium excretion during saline infusion

\begin{tabular}{|c|c|c|c|c|c|c|c|c|c|}
\hline \multirow[b]{2}{*}{ Patient } & \multirow[b]{2}{*}{ Regimen } & \multicolumn{3}{|c|}{ Control* } & \multicolumn{3}{|c|}{ Saline infusiont } & \multirow[b]{2}{*}{$\mathrm{C}_{\mathrm{PAH}} \S$} & \multirow[b]{2}{*}{ F.F. } \\
\hline & & Weight & $\mathrm{U}_{\mathrm{Na}} \mathrm{V} \ddagger$ & $\mathrm{U}_{\mathrm{K}} \mathrm{V}$ & $\mathrm{U}_{\mathrm{Na}} \mathrm{V}$ & $\mathrm{U}_{\mathrm{K}} \mathrm{V}$ & $\mathrm{C}_{\text {In }}$ & & \\
\hline & & $\mathrm{kg}$ & \multicolumn{2}{|c|}{$\mu E q / \min$} & \multicolumn{2}{|c|}{$\mu E q / \min$} & $\mathrm{ml} / \mathrm{min}$ & $m l / m i n$ & \\
\hline D.B. & $\begin{array}{l}\text { Control } \\
\text { Guanethidine }\end{array}$ & $\begin{array}{l}53.66 \\
53.02\end{array}$ & $\begin{array}{r}58 \\
234\end{array}$ & $\begin{array}{l}89 \\
58\end{array}$ & $\begin{array}{r}447 \\
1,276\end{array}$ & $\begin{array}{r}128 \\
89\end{array}$ & $\begin{array}{l}98 \\
88\end{array}$ & $\begin{array}{l}380 \\
344\end{array}$ & $\begin{array}{l}0.26 \\
0.26\end{array}$ \\
\hline Z.M. & $\begin{array}{l}\text { Control } \\
\text { Guanethidine }\end{array}$ & $\begin{array}{l}53.28 \\
56.11\end{array}$ & $\begin{array}{l}39 \\
50\end{array}$ & $\begin{array}{l}55 \\
29\end{array}$ & $\begin{array}{l}248 \\
969\end{array}$ & $\begin{array}{r}69 \\
107\end{array}$ & $\begin{array}{r}68 \\
132\end{array}$ & $\begin{array}{l}311 \\
442\end{array}$ & $\begin{array}{l}0.22 \\
0.30\end{array}$ \\
\hline M.T. & $\begin{array}{l}\text { Control } \\
\text { Guanethidine }\end{array}$ & $\begin{array}{l}58.80 \\
59.93\end{array}$ & $\begin{array}{l}104 \\
242\end{array}$ & $\begin{array}{l}72 \\
15\end{array}$ & $\begin{array}{r}306 \\
1,194\end{array}$ & $\begin{array}{l}62 \\
38\end{array}$ & $\begin{array}{r}88 \\
118\end{array}$ & $\begin{array}{l}387 \\
459\end{array}$ & $\begin{array}{l}0.23 \\
0.26\end{array}$ \\
\hline F.W. & $\begin{array}{l}\text { Control } \\
\text { Guanethidine }\end{array}$ & $\begin{array}{l}61.14 \\
60.80\end{array}$ & $\begin{array}{l}100 \\
135\end{array}$ & $\begin{array}{l}37 \\
12\end{array}$ & $\begin{array}{r}552 \\
1,032\end{array}$ & $\begin{array}{r}152 \\
54\end{array}$ & $\begin{array}{l}108 \\
115\end{array}$ & $\begin{array}{l}523 \\
471\end{array}$ & $\begin{array}{l}0.21 \\
0.24\end{array}$ \\
\hline S.W. & $\begin{array}{l}\text { Control } \\
\text { Guanethidine }\end{array}$ & $\begin{array}{l}52.87 \\
52.62\end{array}$ & $\begin{array}{r}213 \\
51\end{array}$ & $\begin{array}{l}99 \\
55\end{array}$ & $\begin{array}{r}738 \\
1,169\end{array}$ & $\begin{array}{l}131 \\
112\end{array}$ & $\begin{array}{r}98 \\
112\end{array}$ & $\begin{array}{l}540 \\
490\end{array}$ & $\begin{array}{l}0.18 \\
0.23\end{array}$ \\
\hline
\end{tabular}

* Average of three 10-minute periods before saline infusion.

$\dagger$ Maximal values obtained during saline infusion or in the three 10 -minute periods after infusion.

$\ddagger \mathrm{U}_{\mathrm{Na}} \mathrm{V}=$ sodium excretion; $\mathrm{U}_{\mathrm{K}} \mathrm{V}=$ potassium excretion $; \mathrm{C}_{\mathrm{In}}=$ inulin clearance; $\mathrm{C}_{\mathrm{PAH}}=$ para-aminohippuric acid clearance; F.F. = filtration fraction.

$\$$ Average of the values obtained during saline infusion.

of urine by the method of Bonsnes and Taussky (7). For inulin and para-aminohippurate clearances, respectively, alkali-stable inulin was measured by the method of Walser, Davidson, and Orloff (8) and paraaminohippurate by the method of Bratton and Marshall (9).

\section{Results}

Effect of guanethidine on the response to saline infusion. Treatment with guanethidine when the daily intake of sodium was $109 \mathrm{mEq}$ was associated with a gain in body weight in two subjects (Z.M. and M.T.) and no change or a slight loss in the other three (Table I). A typical response of a subject to an infusion of physiologic saline before and again during treatment with guanethidine is shown in Figure 1. In this subject, the rates of sodium excretion in the control periods before infusion were the same with and without guanethidine. In three of the other subjects (D.B., M.T., and F.W.) sodium excretion in the control period was higher, and in one (S.W.) it was lower with the drug (Table I). Infusion of saline always led to a rise in sodium excretion that was more rapid in onset and greater in magnitude (50 to $300 \%$ ) during treatment with guanethidine. The range of maximal sodium excretion was 248 to $738 \mu \mathrm{Eq}$ per minute before guanethidine was given and 969 to $1,276 \mu \mathrm{Eq}$ per minute during treatment with the drug. Control values for potassium excretion were lower during treatment with guanethidine. They rose with saline infusion to maximal values that were still less (except with Z.M.) than those observed during saline infusion in the absence of guanethidine. Average glomerular filtration rates (GFR) were



Fig. 1. Changes in $\mathrm{U}_{\mathrm{Na}} \mathrm{V}, \mathrm{U}_{\mathrm{K}} \mathrm{V}, \mathrm{C}_{\mathrm{In}}$, and $\mathrm{C}_{\mathrm{PaH}}$ WITH INFUSION OF NORMAL SALINE BEFORE AND DURING TREATMENT WITH GUANETHIDINE. $\mathrm{U}_{\mathrm{Na}} \mathrm{V}=$ sodium excretion; $\mathrm{U}_{\mathrm{K}} \mathrm{V}=$ potassium excretion; $\mathrm{C}_{\mathrm{In}}=$ inulin clearance; $\mathrm{C}_{\mathbf{P A}}=$ para-aminohippuric acid clearance. 


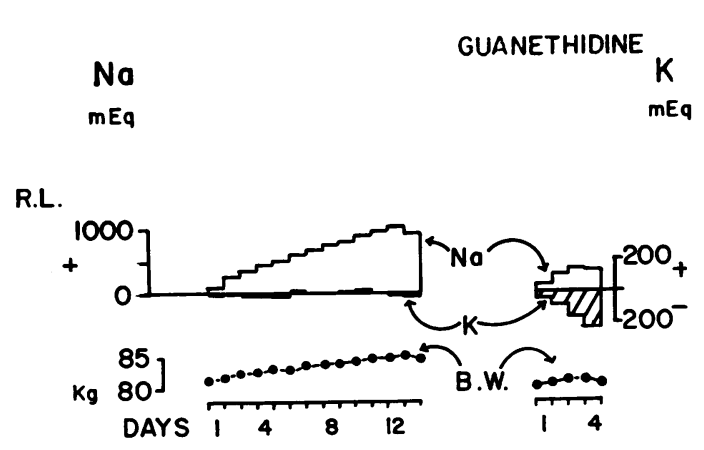

D. B.

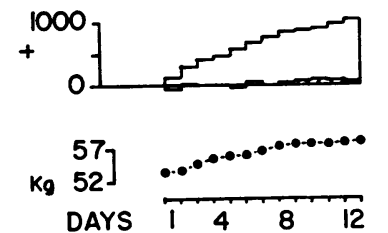

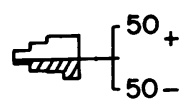

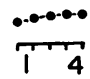

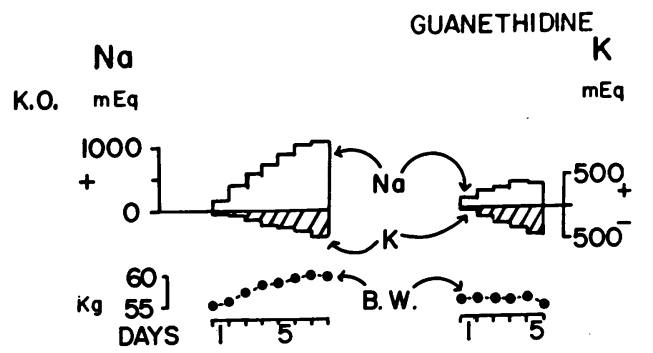

M.T.
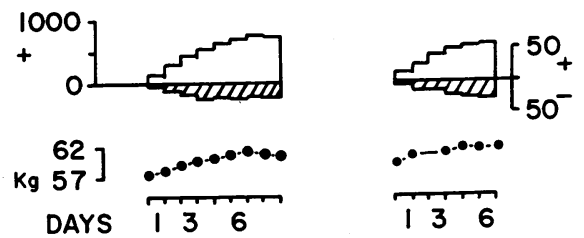

Z. M.
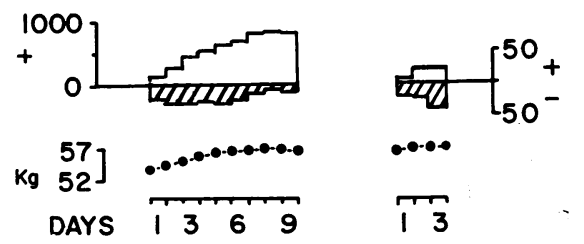

Fig. 2. EFFect OF STEROID ON THE CUMULATIVE GAINS OR LOSSES OF SODIUM AND POTASSIUM AND ON BODY WEIGHT BEFORE AND DURING TREATMENT WITH GUANETHIDINE.

higher in four subjects during treatment with guanethidine, whereas effective renal plasma flow (ERPF) was higher in only two subjects. Filtration fraction (FF) was unchanged (D.B.) or higher with guanethidine.

Effect of guanethidine on the response to sodium-retaining steroids. Treatment with guanethidine when the daily sodium intake was $250 \mathrm{mEq}$ was associated with a gain in body weight in two subjects (2.47 kg in Z.M. and $1.39 \mathrm{~kg}$ in M.T.) and with no change or a slight loss in the other three (compare weight before day 1 , on and off guanethidine, Figure 2). The 24-hour clearances of creatinine $\left(\mathrm{C}_{\mathrm{Cr}}\right)$, serum sodium, and MAP were virtually unchanged by treatment with guanethidine (Table II). When sodium excretion and body weight were stable, steroid treatment was started. A typical response to sodium-retaining steroid before and during treatment with guanethidine is shown in Figure 3 (this is the only subject who did not receive the same steroid for both studies). At this dosage, 2-methyl-9 $\alpha$ fluorohydrocortisone has almost no carbohydrate activity and has at least the sodium-retaining activity of the dosage of DOC (10). When steroid treatment was begun, the initial fall in sodium excretion in the study with guanethidine was the same as it was in the study without guanethidine. With steroid alone, however, retention of sodium continued for 12 days and was accompanied by a weight gain of $3.9 \mathrm{~kg}$, whereas with steroid and guanethidine sodium retention was less prolonged, continuing for only 3 days, and was accompanied by a weight gain of only $1.1 \mathrm{~kg}$. Potassium excretion, unaffected by treatment with guanethidine alone, rose during treatment with steroid and guanethidine to values that were greater than those with steroid alone. The deviations in sodium and potassium excretion from intake values, as cumulative gains or losses, and the changes in body weight with steroid alone and with guanethidine together with steroid, are presented in Figure 2. When steroid alone was given, body weights continued to rise for 7 (K.O. and M.T.) to 12 days (R.L.) with gains in weight of 3.09 (Z.M.) to 4.67 (K.O.) $\mathrm{kg}$ before they be- 


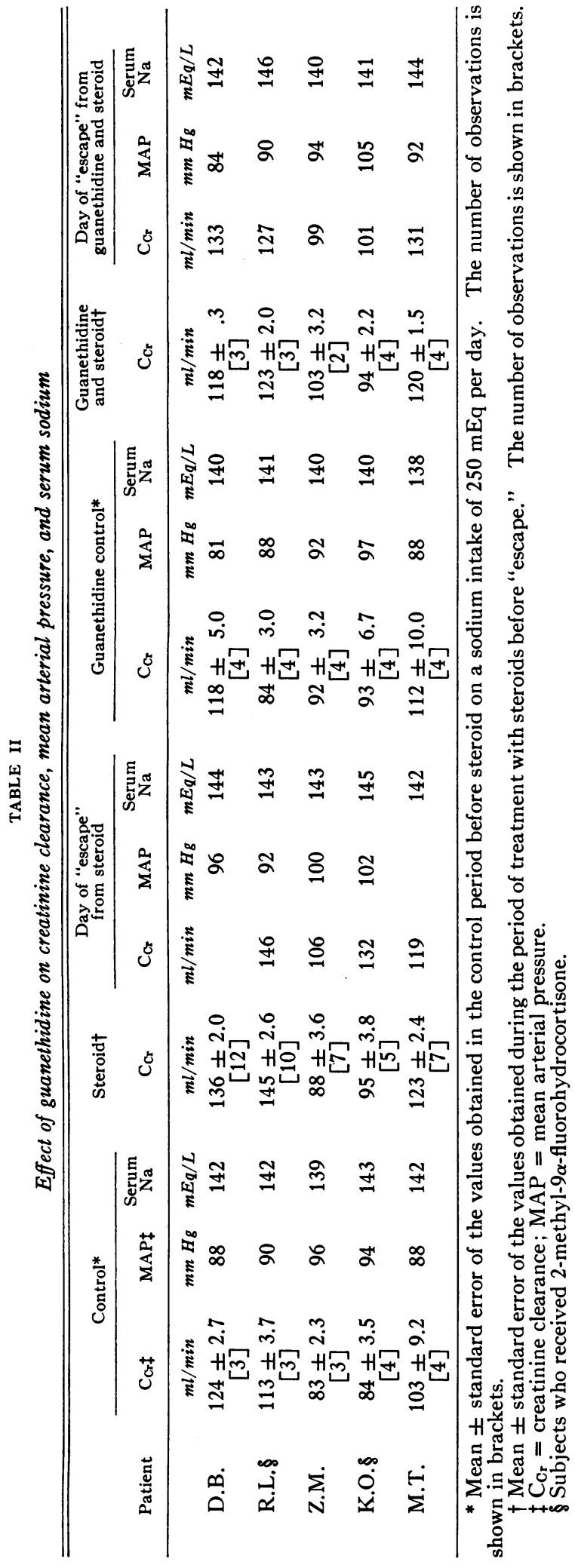

came stable or fell. On day 12, subject D.B. developed marked shortness of breath. She was found to have pleural effusion, a venous pressure of $165 \mathrm{~mm}$ of water, and a Valsalva maneuver compatible with congestive heart failure (Figure 4) (11). The steroid was discontinued. When the subjects ceased to gain weight, their sodium excretion had equaled or exceeded sodium intake for at least a day, and at that time the quantity of sodium which they had retained ranged from 722 (M.T.) to $1,069 \mathrm{mEq}$ (R.L.) (Figure 2). When the steroid was given with guanethidine, body weights rose for 2 (Z.M.) to 6 (M.T.) days with gains in weight of .36 (K.O.) to 2.25 (M.T.) $\mathrm{kg}$ before they became stable or fell. The absolute body weight when weight gain ceased was equal to (Z.M. and M.T.) or less than that at the end of treatment with steroid alone. The quantity of sodium retained ranged from 214 (Z.M.) to 566 (M.T.) mEq. Subject D.B. did not develop shortness of breath during the days before her sodium excretion rose to intake, and her Valsalva maneuver on the day on which her sodium excretion equaled intake did not suggest congestive heart failure (Figure 4). With guanethidine, the cumulative sodium retention on the day on which sodium excretion equaled intake was always less than that on the corresponding day without guanethidine (Figure 2). Potassium excretion during treatment with guanethidine and steroid was equal to (K.O. and M.T.) or greater than that observed throughout the longer periods of sodium retention with steroid alone. Average $\mathrm{C}_{\mathbf{C r}}$ during treatment with guanethidine and steroid was essentially the same as or lower than that observed during treatment with steroid alone and remained so even on the day that sodium excretion rose to intake (Figure 3, Table II). MAP at the end of treatment with guanethidine and steroid was slightly higher than in the control period and was comparable to that observed during treatment with steroid alone. Serum sodium was virtually the same during treatment with steroid and during treatment with steroid and guanethidine. In the two patients in whom it was measured, venous pressure was greater at the end of treatment with steroid alone than at the end of treatment with steroid and guanethidine, 210 (K.O.) and 130 (R.L.) $\mathrm{mm}$ of water as opposed to 165 and 81 $\mathrm{mm}$ of water, respectively. 

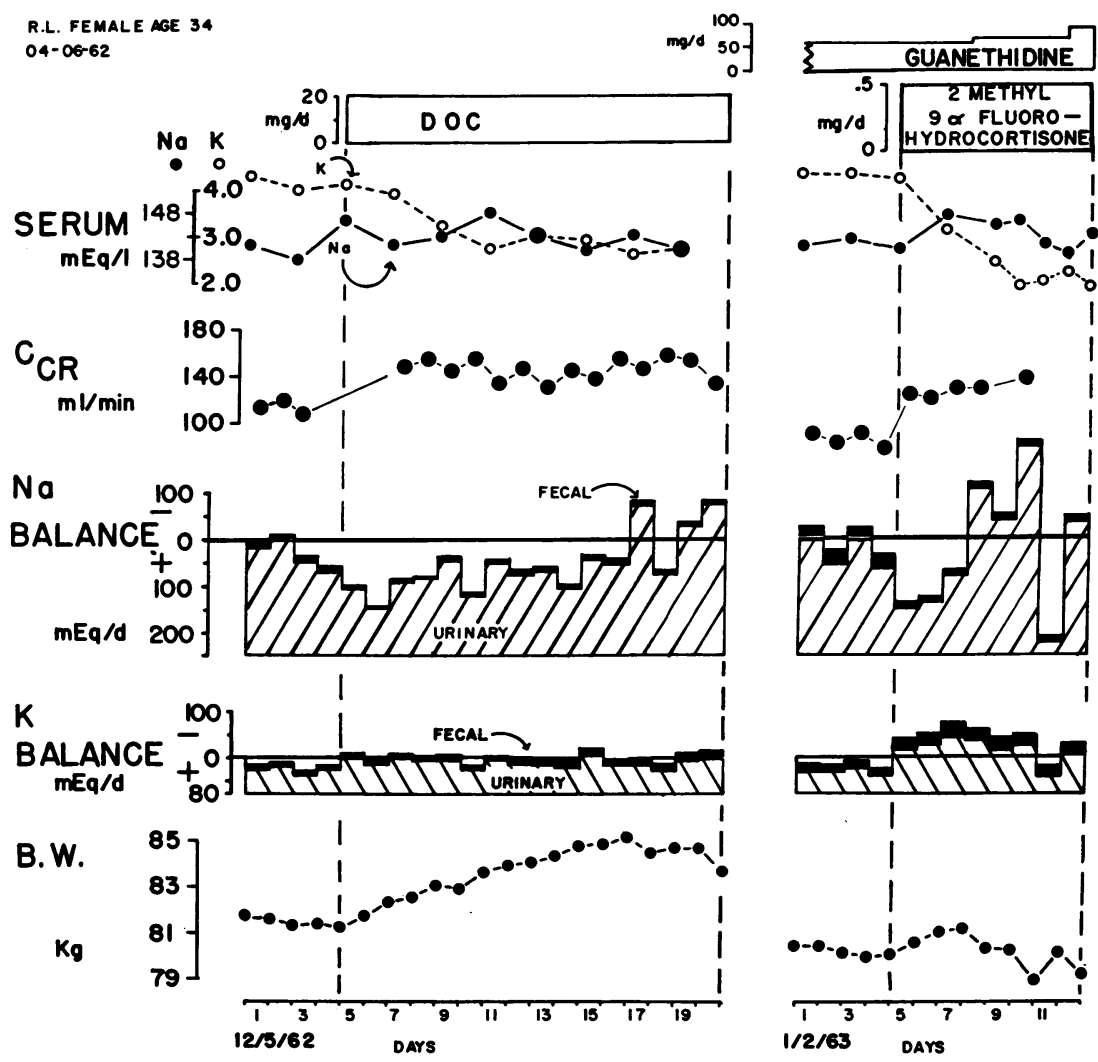

Fig. 3. EFFECT OF STEROID ON SERUM SODIUM AND POTASSIUM, CREATININE CLEARANCE, SODIUM AND POTASSIUM BALANCE, AND BODY WEIGHT BEFORE AND DURING TREATMENT WITH GUANETHIDINE. $\mathrm{C}_{\mathrm{Cr}}=$ creatinine clearance; $\mathrm{B} . \mathrm{W} .=$ body weight ; $\mathrm{DOC}=$ desoxycorticosterone acetate.

\section{Discussion}

Infusion of physiologic saline in normal subjects in whom sympathetic blockade had been produced by guanethidine resulted in a much greater excretion of sodium than did infusion of the same quantity of saline before treatment with the drug (Figure 1, Table I). An enhanced excretion of sodium during an infusion of saline has also been observed in patients who show impaired function of the sympathetic nervous system as a result of disease (4). The patients with autonomic insufficiency exhibit a very labile GFR, which increases much more, upon expansion of extracellular fluid (ECF), than that of normal subjects.

In the present study, GFR measured during infusion of saline was higher with sympathetic blockade in all but one of the subjects. Such an increase in GFR, and thus in the filtered load of sodium, readily provides an explanation for the observed augmentation of sodium excretion.

Sympathetic blockade also produced marked alterations in the response to sodium-retaining steroids of subjects receiving large quantities of dietary sodium. Whereas before treatment with guanethidine, the subjects (except D.B.) showed a limited retention of sodium and gain in weight comparable to those shown by other normal subjects $(12,13)$, during treatment with guanethidine they retained much less sodium and gained much less weight before coming into balance (Figure 2 ). The quantity of sodium retained in the 2 to 6 days until balance was achieved was also less than that retained in a comparable period of time during administration of steroid without guanethidine. Only two subjects (Z.M. and M.T.) gained weight when they were treated with guanethidine alone (Figure 2 and Table I). Thus, an effect of guanethidine on sodium excretion in five pa- 

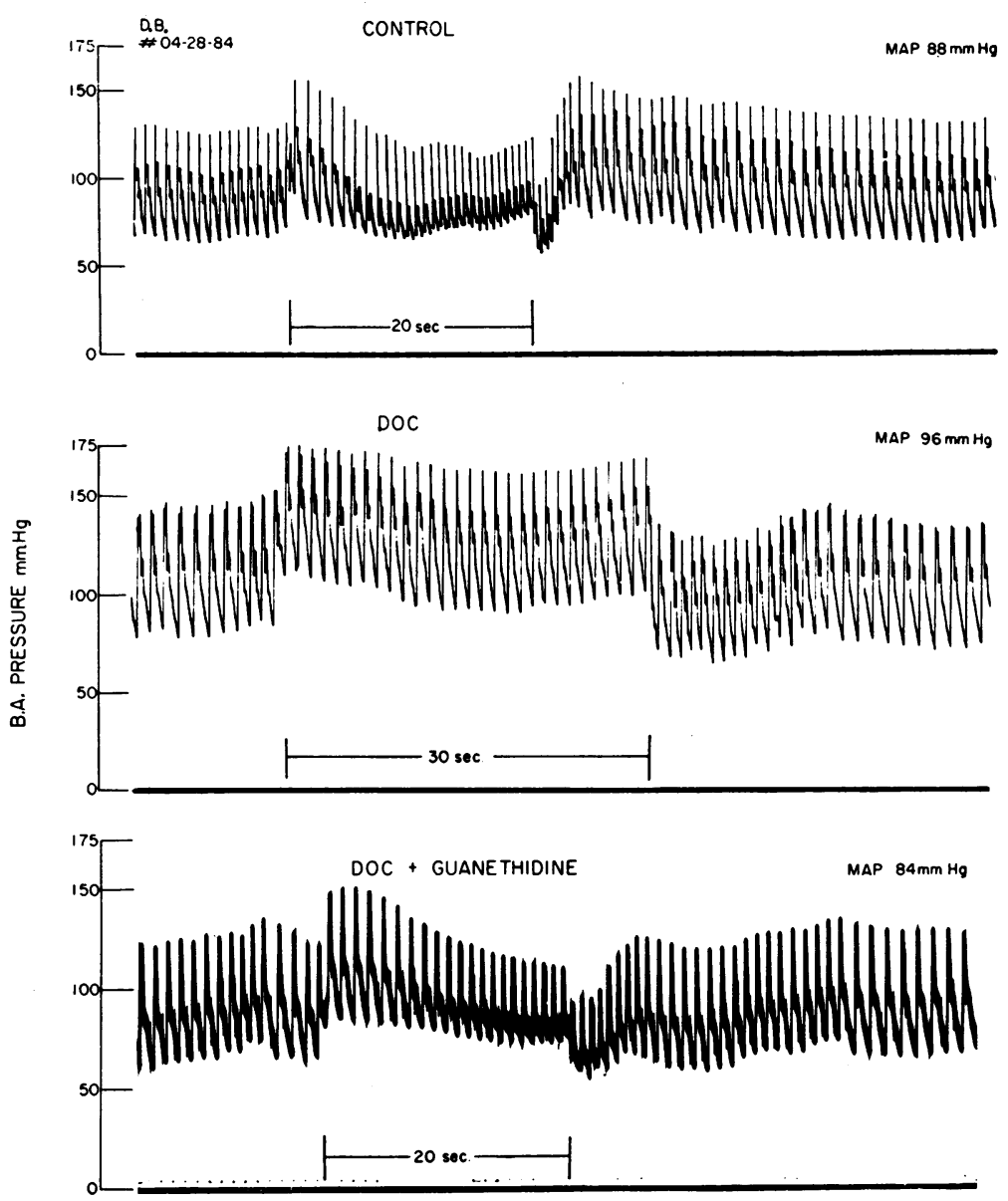

Fig. 4. Valsalva maneuver and mean arterial pressure (MAP) BEFORE (CONTROL), ON THE FINAL DAY OF TREATMENT WITH DESOXYCORTICOSTERONE ACETATE (DOC), AND ON THE FINAL DAY OF TREATMENT WITH DOC AND GUANETHidine. The rise in brachial arterial (B.A.) pressure above base-line values after release of Valsalva maneuver (control) is absent during DOC and guanethidine.

tients during saline infusion and during steroid treatment suggests that this effect is not dependent on a prior expansion of the volume of body fluids.

Potassium excretion, unaffected by treatment with guanethidine alone, increased when steroid was added to equal or exceed that seen throughout the longer periods of sodium retention during treatment with steroid alone. The greater potassium loss with guanethidine suggests that this agent in some way facilitates the delivery of sodium to more distal sites in the nephron where sodium for potassium exchange takes place. The arrival of larger amounts of sodium distally, as well as the achievement of sodium balance after a smaller net retention of sodium during treat- ment with guanethidine and steroid cannot be attributed to a higher GFR, since GFR was comparable to that observed with steroid alone (Table II). In fact, in D.B. and R.L., GFR was somewhat higher with steroid alone when large quantities of sodium were retained and minimal quantities of potassium excreted than it was when guanethidine was given with the steroid (when less sodium was retained and more potassium excreted).

The contribution, if any, of potassium depletion to the "escape" from the effects of sodium-retaining steroids is not clear. The failure of D.B. to "escape" was characterized by the virtual absence of potassium loss. In other studies, minimal po- 
tassium excretion has been noted to accompany excessive sodium retention with sodium-retaining steroids $(14,15)$. In the present studies, there was no apparent decrease of sodium for potassium exchange (resulting, e.g., from potassium depletion) with "escape," since potassium loss on the day of "escape" was as great as, or greater than, that in the preceding days (Figure 2). Conceivably, potassium depletion could, in other ways, affect the filtration or reabsorption of sodium by the kidney.

The effects of guanethidine on sodium excretion appear to be exerted via its pharmacological effects on the adrenergic nervous system. In certain patients even large doses of guanethidine do not produce sympathetic blockade, and in these patients the response to sodium-retaining steroids is not affected (16).

The pharmacological effects of guanethidine on the adrenergic nervous system probably explain the paradoxical sodium retention that may occur when the drug is given to patients in congestive heart failure (17). If the diseased heart, dependent on sympathetic activity (18), loses this support, systems, such as the renin-angiotensin system, which promote sodium retention, may be activated and thus supersede any beneficial effects of lessened sympathetic outflow to the kidney $(19,20)$. The failure of sympatholytic drugs to increase sodium excretion in certain patients with heart failure could be explained in this manner (21). Furthermore, the ability of guanethidine to facilitate both sodium retention and sodium excretion argues against a direct action of the drug on the renal tubule.

Apart from greater rises in GFR in response to expansion of extracellular fluid, the means whereby a decrease in adrenergic stimuli to the kidney facilitates sodium excretion is not clear. As nephrons differ in length (22), a change in the pattern of renal blood flow with a change in sympathetic activity could in turn alter sodium excretion without changing GFR. If, for example, a decrease in sympathetic activity increased the fraction of renal blood flow perfusing juxtamedullary nephrons, with shorter tubules, the fraction of filtered sodium reaching the urine might be increased. Such a theory implies that reabsorption of sodium proximal to the distal tubule is less efficient in some nephrons than in others. A direct effect of norepinephrine on tubular transport of sodium cannot be excluded. Although these studies do not allow a definition of mechanisms involved, they do indicate that in health a normal sympathetic activity or tone limits the excretion of a sodium load and facilitates sodium retention with sodium retaining steroids. Indeed, it is also probable that the sympathetic nervous system plays an important role in renal sodium metabolism in disease (23).

\section{Summary}

The response to rapid infusion of physiologic saline ( $2 \mathrm{~L}$ in 120 minutes) and the response to sodium-retaining steroids and large quantities of dietary sodium (250 $\mathrm{mEq}$ per day) have been studied in normal subjects before and after adrenergic blockade with guanethidine. Sodium excretion during infusion of saline was 50 to $300 \%$ greater after adrenergic blockade and was associated with a higher clearance of inulin.

During treatment with steroid (desoxycorticosterone acetate, $20 \mathrm{mg}$ per day, or 2-methyl-9 $\alpha^{-}$ fluorohydrocortisone, $0.5 \mathrm{mg}$ per day) sodium retention and weight gain were less after blockade, 214 to $566 \mathrm{mEq}$ and 0.36 to $2.25 \mathrm{~kg}$, as opposed to 722 to $1,069 \mathrm{mEq}$ and 3.09 to $4.67 \mathrm{~kg}$. The much smaller quantities of sodium retained with guanethidine and steroid were associated with losses of potassium that equaled or exceeded those observed throughout the longer period of sodium retention with steroid alone. This increase in excretion of sodium and potassium with guanethidine was not dependent on a higher glomerular filtration rate.

The adrenergic nervous system appears to play an important role in sodium metabolism in normal man, probably through an effect on the renal vasculature.

\section{References}

1. Barger, A. C., F. P. Muldowney, and M. R. Liebowitz. Role of the kidney in the pathogenesis of congestive heart failure. Circulation 1959, 20, 273.

2. Brod, J., Z. Fejfar, and M. H. Fejfarova. The role of neuro-humoral factors in the genesis of renal haemodynamic changes in heart failure. Acta med. scand. 1954, 148, 273.

3. Nickel, J. F., C. McC. Smythe, E. M. Papper, and S. E. Bradley. A study of the mode of action of the adrenal medullary hormones on sodium, 
potassium and water excretion in man. J. clin. Invest. 1954, 33, 1687.

4. Wagner, H. N., Jr. The influence of autonomic vasoregulatory reflexes on the rate of sodium and water excretion in man. J. clin. Invest. 1957, 36, 1319.

5. Maxwell, R. A., A. J. Plummer, F. Schneider, H. Povalski, and A. I. Daniel. Pharmacology of [2-(octahydro-1-azocinyl)-ethyl]-guanidine sulfate (SU-5864). J. Pharmacol. exp. Ther. 1960, 128, 22.

6. Gaffney, T. E., C. A. Chidsey, and E. Braunwald. Study of the relationship between the neurotransmitter store and adrenergic nerve block induced by reserpine and guanethidine. Circulat. Res. 1963, 12, 264.

7. Bonsnes, R. W., and H. H. Taussky. On the colorimetric determination of creatinine by the Jaffé reaction. J. biol. Chem. 1945, 158, 581.

8. Walser, M., D. G. Davidson, and J. Orloff. The renal clearance of alkali-stable inulin. $\mathrm{J}$. clin. Invest. 1955, 34, 1520.

9. Bratton, A. C., and E. K. Marshall, Jr. A new coupling component for sulfanilamide determination. J. biol. Chem. 1939, 128, 537.

10. Liddle, G. W., J. E. Richard, and G. M. Tomkins. Studies of structure-function relationships of steroids : The 2-methyl-corticosteroids. Metabolism 1956, 5, 384.

11. Knowles, J. H., R. Gorlin, and C. F. Storey. Clinical test for pulmonary congestion with use of the Valsalva maneuver. J. Amer. med. Ass. 1956, 160, 44.

12. Relman, A. S., and W. B. Schwartz. The effect of DOCA on electrolyte balance in normal man and its relation to sodium chloride intake. Yale J. Biol. Med. 1952, 24, 540.

13. August, J. T., D. H. Nelson, and G. W. Thorn. Response of normal subjects to large amounts of aldosterone. J. clin. Invest. 1958, 37, 1549.
14 Nelson, D. H., and J. T. August. Abnormal response of œdematous patients to aldosterone or deoxycortone. Lancet 1959, 2, 883.

15. Mills, I. H. Sodium-retaining steroids in nonœdematous patients. Production of œdema and heart-failure. Lancet 1962, 1, 1264.

16. Gill, J. R., Jr., D. T. Mason, and F. C. Bartter. Unpublished observations.

17. Gaffney, T. E. and E. Braunwald. Importance of the adrenergic nervous system in the support of circulatory function in patients with congestive heart failure. Amer. J. Med. 1963, 34, 320.

18. Chidsey, C. A., D. C. Harrison, and E. Braunwald. Augmentation of the plasma nor-epinephrine response to exercise in patients with congestive heart failure. New Engl. J. Med. 1962, 267, 650.

19. Merrill, A. J., J. L. Morrison, and E. S. Brannon. Concentration of renin in renal venous blood in patients with chronic heart failure. Amer. J. Med. 1946, 1, 468.

20. Biron, P., E. Koiw, W. Nowaczynski, J. Brouillet, and J. Genest. The effects of intravenous infusions of valine-5, angiotensin II and other pressor agents on urinary electrolytes and corticosteroids, including aldosterone. J. clin. Invest. 1961, 40, 338.

21. Bartter, F. C., D. S. Gann, and J. P. Thomas. On the mechanisms of sodium retention in cardiac and hepatic disease in Human Adrenal Cortex. Glasgow, E. S. Livingstone, 1960, p. 294.

22. Bradley, S. E., J. H. Laragh, H. O. Wheeler, M. MacDowell, and J. Oliver. Correlation of structure and function in the handling of glucose by the nephrons of the canine kidney. J. clin. Invest. 1961, 40, 1113.

23. Fejfar, Z. Water and electrolyte metabolism in congestive failure in Water and Electrolyte Metabolism in Relation to Age and Sex, Ciba Foundation Colloquia on Ageing. Boston, Little, Brown, 1958, vol. 4, p. 271.

\section{SPECIAL NOTICE TO SUBSCRIBERS}

Post Offices will no longer forward the Journal when you move.

Please notify The Journal of Clinical Investigation, Business Office, 10 Stoughton Street, Boston 18, Mass., at once when you have a change of address, and do not omit the Zip Code number if there is one. 